\title{
Cutaneous Melanoma cNX TNM Finding v7
}

National Cancer Institute

\section{Source}

National Cancer Institute. Cutaneous Melanoma cNX TNM Finding v7. NCI Thesaurus.

Code C88400.

Cutaneous melanoma in which the regional lymph nodes cannot be assessed (e.g., previously removed for another reason). (from AJCC 7th Ed.) 